Journal of Teacher Education for Sustainability, vol. 15, no. 2, pp. 78-90, 2013

\title{
PRIMARY SCHOOL TEACHERS' VIEWS ON A HOLISTIC APPROACH TO FACILITATING THE ACQUISITION OF MUSICAL CULTURAL VALUES
}

\author{
Jel̦ena Badjanova \\ Daugavpils University, Latvia
}

\begin{abstract}
Recent tendencies in education highlight the need to align the system of general education in Latvia with the tenets of sustainability. In keeping with this broad target orientation, this paper re-examines international and Latvian experiences and perspectives on the application of a holistic approach to the content of primary education. This review of good practice is set against the backdrop of different theories and approaches concerned with the essence and principles of holism. More specifically, the paper addresses the issue of ensuring successful acquisition of musical cultural values in primary school via a holistic approach. In this regard, the latter is construed as movement towards the new that facilitates positive attitudes towards musical cultural values among learners and is both physically and spiritually nurturing. The paper proposes a theoretically and empirically grounded model for the usage of a holistic approach with a view to enabling acquisition of musical cultural values in primary school. The gradual development of the model is traced in the course of theoretical and empirical inquiry, the latter involving a survey and an interview with five experts.
\end{abstract}

Key words: values, musical culture, musical cultural values, holistic approach, sustainable development, holistic development, primary school teachers

\section{Introduction}

Various studies (Little, 1991; Kopeloviča \& Žukovs, 2004; Maslo, 2006; Salite \& Pipere, 2006; Quince, 2006; Katane, 2007) discuss the need for conceptual changes in education. International normative documents contain lengthy discussions about imminent educational reforms. For instance, the United Nations Economic Commission for Europe Report dating from 2011 (United Nations Economic Commission for Europe, 2011) clearly states that education should be reoriented to target skills and positive attitudes, critical thinking and creativity. Also, an interdisciplinary approach is discussed in this document, focusing on solutions to real life problems. Unfortunately, most of the approaches currently in use in educational contexts are designed to facilitate knowledge acquisition and fail to address the development of fundamental skills, capabilities and attitudes (United Nations Economic Commission for Europe, 2011). 
In this paper, a holistic approach is analysed in the context of content delivery in primary education. Drawing sharp distinctions between the stages of primary education is considered irrelevant; instead, the system of primary education is viewed in its entirety, in keeping with the principle of unity in a holistic approach (Schreiner, 2005). The paper re-evaluates the theoretical and contextual content aspects in formal and holistic education as well as illuminates the views of Latvian primary education teachers regarding the viability of using a holistic approach to support the acquisition of musical cultural values in primary school. Thus, this research aims to ascertain the views of primary education teachers on a holistic approach with a view to designing a theoretically and empirically grounded model for the usage of a holistic approach to facilitate acquisition of musical cultural values at all stages of primary education.

\section{A holistic approach and the content of primary education: Theoretical perspective}

In many studies (Miller, 1993, 2000; Capra, 2002; Forbes, 2003), a holistic approach is construed as a possibility to facilitate learners' integral development, which should be spiritual as well as physical. Several researchers (Belickis, 2000; Salite, 2002) argue that the formation of learners' individual experiences and their making unique discoveries is contingent on the teaching strategies employed in primary school. Hence the need to integrate different approaches and insights of established scholars into primary school teachers' practice, which should rest on the application of a holistic approach and its integrated content (Wilber, 2001) with a view to contributing to the learners' sustainable development is equally important.

Much research on a holistic perspective in education has been done both globally (Schreiner, 2005; Bundsgaard \& Hansen, 2011) and in Latvia (Sīle, 2000; Ilisko, 2005; Salite, 2008; Pelnēna \& Kḷaviňš, 2009). A holistic approach to education represents a facet of sustainable development which manifests itself in educational practice (Rose, 2005). It rests on an assumption that access to education is insufficient in itself, which means that quality and quantity are recognised as equally important, and learner-centredness is a fundamental aspect of education (Salite, 2002; Pelnēna \& Kḷavin̄š, 2009).

As suggested above, a holistic approach to education has been thoroughly studied. Palmer (1998) construes it as integrated schooling. Miller (1993) defines it as education that focuses on the links between mind and body, between linear thinking and intuition, among different scientific disciplines, between individual and community, between the individual self and the transcendent self $-\mathrm{a}$ distinction underpinned by an assumption that spiritual traditions exist independently of discrete human egos. Miller (1993) also refutes dividing schooling into stages and advocates viewing it as a continuous process that features subtle transitions from concrete to abstract concepts.

Miller (2000) attempts to deconstruct the concept of life in the context of holistic education and its theory. For Miller, human life is a target, a direction, a meaning and a purpose that transcends one's personal ego and particular physical or cultural conditions.

According to Lemkow (1990), holistic education aims to bridge the gaps in contemporary civilisation that dichotomises mind and body, intellect and emotion, rationality and intuition, science and art, individual and society, humanity and nature. 
Forbes (2003) considers holistic education to be formative and underpinned by faith in learner's independence and capacity for decision making. An analysis of Forbe's studies enables one to pinpoint the target orientation of a holistic approach - that of reshaping the learning process to enrich learners' social experience.

Nava (2001) distinguishes between mechanistic and holistic educational paradigms, compares a mechanistic, formal and a holistic teacher and lists the key features of holistic education with a particular emphasis on the intrinsic connections between science, ecology, society and spirituality.

Clark (1997) explores complex issues such as spiritual life and its value system, integrality and connections with the Universe.

Gang (1993) perceives the content of holistic education as a synthesis of concepts, freedom of choice at every point of the learning process, spirituality, connections throughout human life as well as interdisciplinary relations. According to Gang (1993), to create the subject matter of a holistic education, it is the learning environment that should be shaped to accommodate both individual and group learning, thereby facilitating analytical and inductive thinking and by process- rather than outcome-oriented strategies.

Based on the opinions of representatives of holism (Gang, 1993; Schreiner, 2005; Rose, 2005), it is possible to define miscellaneous aspects of the content of holistic education. Firstly, holistic education is transformative. It requires transformation in both individuals and communities. Hence it also demands transformation of educational institutions, policies and actions which would result in the establishment of holistic practices at all levels of education. Holistic education asks for a multidisciplinary perspective, and it invites addressing the development of an individual as a whole and recognising the mutual dependencies of theory, research and practice. Secondly, in order to achieve the aforementioned transformation, holistic education should make use of various means and different approaches. Holistic education should enhance a person's ability to develop critical competence through the analysis of diverse social and political contexts as well as facilitate life-affirming practice. Thus, holistic education can be interpreted as the antithesis of the material perspective that currently permeates human thinking and action. Thirdly, researchers respect new developmental tendencies in different branches of science and philosophy that have embraced holism and holistic thinking. Fourtly, holistic education addresses the development of individuals as a whole within the context of a community, including their physical, social, moral, aesthetic, creative and spiritual being as well as their intellectual and professional development. Meanwhile, nowadays formal education tends to be cognitively-oriented and neglect other essential dimensions of human life. Fiftly, holistic education respects the uniqueness and creativity of individuals and communities while recognising their interrelatedness. It attests to the possibility of establishing true learning communities where people learn from each other's differences, appreciate each other's strengths and develop the willingness and ability to help each other. Sixthly, holistic education facilitates active participation in the global community. It encourages mutual understanding and respect towards the diversity of cultures and religions which are now brought closer together than ever before in the history of civilisation. Seventhly, holistic education encompasses the depths of human nature that elucidate the spiritual grounds of reality. It is the issue of harmony between internal and external life. Eighthly, holistic education facilitates the creation of new knowledge as well as new practices of teaching and learning that involve reflection and action. 
In Latvia, a holistic approach to facilitating the acquisition of musical cultural values has not been researched widely. Therefore the following section of the paper highlights the importance of a holistic approach to facilitating the acquisition of musical cultural values in primary school, considering experience of both international and national theoreticians and practitioners.

\section{A holistic approach to facilitate the acquisition of musical cultural values in primary schools}

In the context of music pedagogy, Zarinš (2003) defines musical culture as the entirety of music-related material and spiritual values created as a result of the humankind's physical and spiritual labour. Among the creators of musical cultural values, he includes professionals who participate in the processes inherent in musical culture - teachers, learners, the audience, musicians and composers. Meanwhile, musical culture is construed as a relatively autonomous system of values that exist within a particular system of music making (Zarinš, 2003).

Several researchers (Jorgensen, 1997; Ruismäki \& Juvonen, 2009) acknowledge that, by taking the view of culture as a system of values created by humanity, musical culture becomes a system of musical values and musical creation, which makes musical cultural values a complex set of spiritual phenomena underpinned by a specific notion of beauty, a certain mentality, a particular environment and relevant samples of musical culture.

Bezborodova and Aliyev (2002) maintain that learners should develop unbroken, whole notions of the art of music for continued self-education through autonomous interaction with art. Consequently, they argue that musical education in primary school should aim for the following:

- artistic and figurative inquiry with a view to cognising the world;

- feelings of belonging and altruism in one's relationship with the world;

- emotional growth and development of the culture of feelings;

- humanistic and spiritual development;

- acquisition of national and universal, past and present musical cultural values;

- nurturing creativity;

- integration of learners' personality traits into national and global artistic culture.

Bezborodova and Aliyev (2002) recommend teaching music by retaining and reinforcing the implicit connections among music, other forms of art, nature and human life rather than focusing on distinct forms of artistic expression that are forced out of the context of the greater whole.

Ruismäki and Ruokonen (2009) underscore that teachers ought to facilitate learners' social, cultural and creative development and help them form a holistic attitude towards musical cultural values with a view to orienting learners towards retaining sustainable attitudes in the long run. At the same time, the content rather than the outcomes of learning should be emphasised in the teaching and learning process concerned with multicultural and global issues (Ruismäki \& Juvonen, 2009). Wilber (2001) suggests examining any phenomenon, whether individually or in groups, by integrating subjective and spiritual experiences and awareness into a single system that yields objective descriptions of the 
material, biophysical and empirical world. According to Wilber (2001), such a holistic approach bears favourably on the four aspects of human existence: individual or mental experience, examination of behavioural or physiological processes, cultural and social existence.

Jorgensen (1997) maintains that art should be used as a link that brings together spiritual and earthly worlds to enable learners to perceive the nuanced beauty of musical cultural values. He proposes an interdisciplinary approach to the understanding of musical cultural values and argues in favour of integrating music-related knowledge and skills into other realms of human experience: children learn in an unbroken, direct (natural) and cohesive fashion, and music making is not an isolated occurrence in their lives. According to Jorgensen (1997), learners make music a set of interrelated elements integral to their daily life; they can make music during any lesson and at any time. Birzkops (1999) observes that music making involves several interrelated components thinking, hearing, memory, rhythm, movement and emotion, successive and simultaneous perception. When performing songs with lyrics, both mnemonic forms are activated at the same time - verbal memory and short-term musical memory. Playing a musical instrument is a complex psychological act that can be examined through the prism of different scientific branches - not only the theory of music or psychology of music and instrument play, but also mathematical psychology, kinaesthetic physiology, neurology and even psycholinguistics. According to Birzkops (1999), knowledge can be accumulated throughout one's entire lifetime whereas the time one has to develop one's abilities is fairly limited.

Cropley's (1999) research into creativity boils down to the conclusion that creative activity requires striking a fine balance between the social environment and an individual's personality traits, attitudes, perceptions of reality and acceptance of the latter.

A holistic approach to the perception of musical images can be discussed in the context of a values-oriented education as construed by Belickis (2000), who argues that the latter can be values-oriented only provided that it is implemented in keeping with the principle of holism. He concludes that a values-oriented lesson warrants an emotional experience of spiritual values as uniform structures in conditions conductive to understanding fundamental ideas implicit in specific values. According to Beliickis (2000), an entirety, a complex and a whole are related concepts that denote an attitude towards the objective which is tantamount to that towards the subjective.

All the aforementioned theoretical considerations suggest the principles of applying a holistic approach to facilitating the acquisition of musical cultural values. Most importantly, artificial distinction of implicitly related concepts, actions and developmental areas is pointless. What is more, the original, historical perspective on creative musical activity is not that of artificial categories such as musical styles, forms, rhythm or tune or their arbitrarily isolation from the human being and Nature viewed as a whole; a holistic approach to facilitating the acquisition of musical cultural values features an inclusive philosophical conception of music as an empirical, analytical, holistic, natural and uniform phenomenon.

The following section of the paper proposes a review of the empirical groundings of the model of a holistic approach and its application to facilitating the acquisition of musical cultural values that was developed by the author of this paper. 


\section{Research instrument and participants}

The research stage of 2012/2013 featured a focus group interview with experts (Creswell, 2003). The research instrument was expressly designed with a view of creating a viable theoretically and empirically grounded model of a holistic approach to facilitating the acquisition of musical cultural values. It was hoped that primary school teachers might find this model useful for shaping the content of primary education. The following phases can be identified in the aforementioned study: focus group interview with experts in preparation for designing the model; generalisation of findings from theoretical and empirical investigations; a model design and expert interpretation of data.

The focus group interview involved 10 primary education teachers from 10 primary schools from different regions of Latvia. Specific criteria were set for granting prospective participants an expert's status and thereby validating their suitability for the study. The mean age of the participants was 44.5 years with $25 \%$ of the cohort older than 50 ; meanwhile, their mean pedagogical experience was 20 years.

Carefully worded questions were used in order to procure more accurate and detailed information:

How much and what kind of valuable and valid fundamental components and conditions would you recommend for inclusion in a theoretically and empirically grounded educational model?

What categories of learners' development would you recommend targeting in holistic acquisition of musical cultural values?

Do you consider the content of the categories of learner development as befitting the criteria for evaluating learners' acquisition of musical cultural values at all levels of primary education?

Every expert's evaluation was given separately from other experts. The procured individual evaluations were eventually combined through content analysis. Ethical concerns inherent in the usage of focus group interviews required preservation of participant teachers' anonymity, so their names were coded.

\section{Findings and their interpretation}

Most experts who participated in the focus group emphasise that successful application of a holistic approach requires creative teachers who are capable of developing their learners' creativity and figurative and constructive thinking (Forms 1-9) with due regard for the course of their psychic and physical development. The experts' assumptions about musical cultural values appear up-to-date and conductive to the formation of learners' attitudes towards the humanity's shared cultural experience, supportive of learners' active participation in the creation of new material and spiritual values and bearing a favourable influence on their acquiring and retaining a stable positioning and orientation towards particular values. For instance, one expert believes that acquisition of musical cultural values involves a particular individual and social experience the hallmarks of which are love towards musical art, emotionality with regards to it and a cultured musical taste (Arija). The experts are unanimous in singling out learners' participation in various kinds of musical activity. They advocate a holistic approach to the art of music, which takes into account the humanity's universal cultural context and 
makes use of innovative ideas and novel forms of aesthetic education with a view to facilitating the acquisition of musical cultural values. This is considered important not only in regard to autonomous development of each learner's spirituality but also to their social life. As to music lessons in primary school, the experts embrace the idea of incorporating acquisition of musical cultural values into the content of all school subjects as well as emphasise the importance of networking among schools. In addition, the experts argue in favour of taking a holistic perspective on the teaching and learning process and underscore the diversity and multiplicity of cross-subject connections.

In the proposed theoretically and empirically grounded model, the principle of unity is evaluated by the experts as its amalgamating component. What is more, they underscore its importance in acquiring musical cultural values and lament the fact that this process still focuses on teaching discrete topics, which is not seen as conductive to simultaneous all-round development of learners in the framework of one lesson. The experts approve the proposed indicators of reflection and claim that this model could change not only the learners' but also the teachers' attitude towards musical cultural values and the very process of their acquisition because, as a rule, this process requires methods that facilitate understanding of meaning rather than formal memorisation ... frontal work with learners has become an established practice, which should change... any kind of monotony, including an unvarying mood, kills learners' interest (Erika).

The study suggests that the key criterion for evaluating the acquisition of musical cultural values is combining learners' cognitive activity and emotional resonance with music to solve various creative tasks both in groups and individually. The perspective of 10 experts of a holistic approach to facilitate the acquisition of musical cultural values in primary schools in different regions of Latvia enabled the author to create a theoretically and empirically grounded model the fundamental components of which include categories that mark the level of learners' development, school lessons concerned with acquisition of musical cultural values and aspects of reflection. Practical application of the model warrants further investigations.

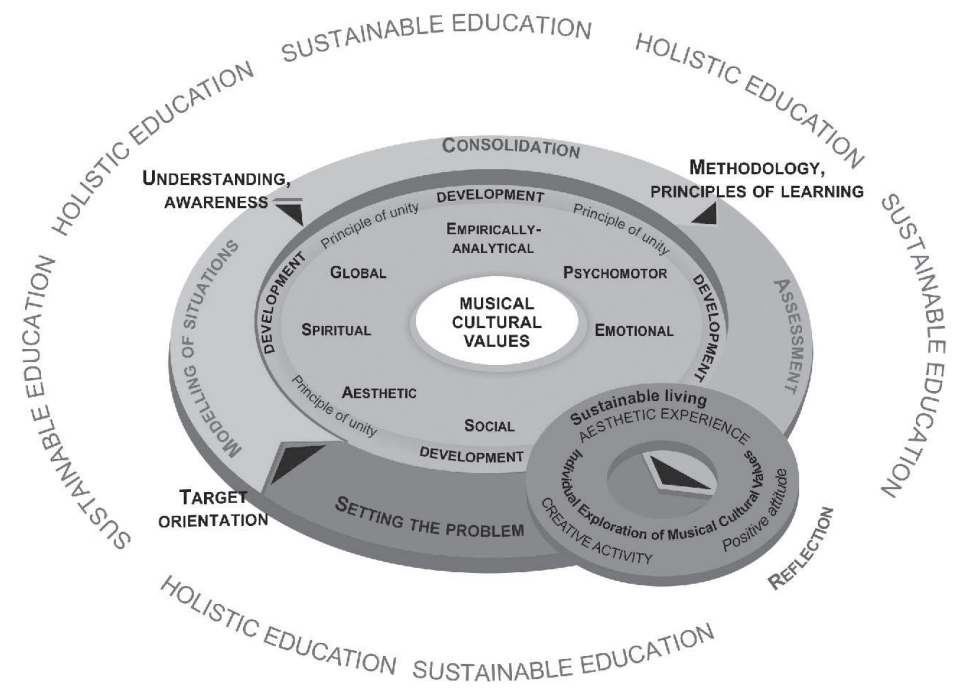

Figure 1. A theoretically and empirically grounded model of a holistic approach to facilitate the acquisition of musical cultural values 
The content of the proposed model is grounded in features of sustainable education and those of holistic education viewed as a manifestation of sustainability in education.

Features of sustainable education: understanding of musical cultural values, responsibility and respect towards them and the totality of humanity's cultural legacy; positive attitude towards the necessity to preserve this legacy for future generations. Learners demonstrate understanding of musical cultural values that are vital for sustainable development - improve the quality of their lives and those of future generations without destroying the planet, understand and are able to envisage desirable future as well as assess the chancesof achieving it. When forming learners' beliefs about living in harmony with the environment, teachers should focus on self-awareness - learners ought to be aware of their responsibility for achieving sustainability. Pedagogical practice is oriented towards facilitating learners' awareness of their lifestyle and guiding them towards the vision of ecological and social sustainability - the new planetary vision (Sterling, 2004).

Features of holistic education: learners' physical and spiritual development in all its manifestations viewed systemically. A holistic approach to facilitating the acquisition of musical cultural values inprimary school is underpinned by interrelatedness and interaction among such components of the teaching and learning process as content, organisation and social relations as well as by teachers drawing from the totality of diverse methods and pedagogical techniques. While facilitating the acquisition of musical cultural values, the teacher does not separate, for instance, the integrated approach from the humanistic one but rather views them as indivisible and highlights the individualistic approach that focuses on all-round development of the learner's personality as quality warranty of the teaching and learning process. A favourable learning environment is construed as the classroom atmosphere that emerges from the quality of the teacherlearner relationship and encourages creative learning. During a school lesson, the learners' creative activity shapes their individual musical experience. Thus, a holistic approach to facilitating the acquisition of musical cultural values combines the creative process with the development of learners' thinking processes, intellectual capabilities and experience.

Observation of the features of sustainable and holistic education requires shaping the teaching and learning process in ways that make acquisition of musical cultural values beneficial for the learner.

The conceptual basis of the proposed theoretically and empirically grounded model of a holistic approach for facilitating the acquisition of musical cultural values is complex.

Individualisation and differentiation of learning. The teaching and learning process should consider alternative possibilities and conditions for reaching the intended outcomes as well as respect each learner's interests, individual needs and natural involvement in creative activities (Krastinga \& Pipere, 2004). Individualisation of outcomes is based on learners' prior knowledge and psychic development. Learners' activity, whose quality and effectiveness are contingent on their current emotional state and self-assessment. For this reason, instructional activities should target learners' abilities (Gardner, 1993) by using different learning styles as well as seek to promote learners' spiritual and physical developmentvia appropriate content selection and adequate choices as regards the methods of its delivery (Beyers, 2009).

Social constructivism. This conception underpins concern for development of learners' social flexibility (Powell \& Kalina, 2009) which will enable their social integration. Learning is construed as an interactive process - learners' ability to build relationships, exercise communication skills and develop knowledge and skills in cooperation 
with other learners. Thus, the teaching and learning process is interpreted in ecological terms as one that considers the needs of learners, school, family and society. Teachers should help learners master essential competences and skills that would assist their social adaptation (Krastina \& Pipere, 2004).

Humanistic approach. This approach to the organisation of the teaching and learning process is learner-centred; the teacher performs the role of advisor (Rogers, 1967; Kopeloviča \& Žukovs, 2004). At the same time, the teacher's concern is harmonising learners' freedom with perceived needs as well as supporting their autonomy (Little, 1991). In this respect, an empathetic understanding and an ability to see the world through the eyes of the learners is crucial (Bateson, 2000).

Integrated approach. It is focused on practical activity and targets learners' critical thinking (Rubene, 2008) and creativity (Sïle, 2000) that are addressed through constructing educational situations. Content acquisition is oriented towards developing basic skills vital for the learners' social integration. The approach is underpinned by Wilber's (2001) insights about the union on the systemic level as well as on that of the worldview which includes learners' consciousness: objects are construed as complex systems, as natural compounds that include the human in an essential way. Meanwhile, the universe is interpreted as a network of interrelated occurrences. Interdisciplinary connections are another essential worth mentioning.

Shaping a holistic learning environment. It requires teachers' professional development and self-actualisation on the personality level while creating a trusted, interdisciplinary learning environment (Powell \& Kalina, 2009) because integration and trust are the structural bedrock of a learners' personality. Lack of trust in a relationship generates fear, which limits the natural opportunities for learners' personality development. In teacher-learner interaction, dominance should be relinquished in favour of partnership (Ilisko, 2005). Fundamental decisions that concern all aspects of the teaching and learning process should be made jointly by teachers, learners and school administration.

Principle of holism or unity. It means observing the interrelatedness and interdependence of all components in the teaching and learning process, which requires a shared understanding on the part of the teacher and the learners about the subject matter and the methods of its acquisition (Kostakos, 2012). In the proposed model, all categories are connected in keeping with this principle. It also involves targeting the acquisition of musical cultural values as a whole in that the contents of the categories in the model envisage learners' holistic development in the framework of one lesson.

To recapitulate, application of a holistic approach to the acquisition of musical cultural values transforms it into a creative and artistic process. Acquisition becomes a process that involves emotional, physical, social and spiritual levels of learners' consciousness. Teaching is no longer perceived as transfer of ready-made knowledge but rather viewed as a means to encourage transformation. Knowledge is conceived broadly as an integration of scientific elements, logics, intuition, cognition, aesthetics and spirituality. Thus, a holistic approach to facilitating the acquisition of musical cultural values can ensure that learners not only understand and interpret knowledge, but also become actively and creatively involved in the lesson. Theoretical and empirical inquiry enabled the author to create the above-described holistic model for facilitating the acquisition of musical cultural values at all levels of primary education. 


\section{Concluding reflections}

The findings from the experts' interviews suggest that designing a model of a holistic approach to facilitating the acquisition of musical cultural values in primary school requires taking the following fundamental steps:

- formulation of structural components that include all principles of each learner's holistic development;

- anticipation of content-related categories that enable evaluation of the acquisition of musical cultural values at the end of the lesson or upon completion of the three stages of primary education;

- differentiation of principles that regulate the application of a holistic approach;

- inclusion of structural elements of lesson delivery and continuity to ensure holistic acquisition of musical cultural values;

- definition of criteria that enable evaluation of the acquisition of musical cultural values;

- consideration of the following fundamental aspects of lesson planning in keeping with each learner's individual needs: the principle of unity; sustainable approach; facilitation of reflection; a process-oriented lesson; integration of specific values into the aims and objectives of other lessons; integration of subject matter into different contexts to facilitate understanding of their importance in modern life; differentiated evaluation in keeping with the content and principles of a holistic approach; purposefully organised activities presenting values to become learners' personal gains.

It can thus be concluded that what matters most in facilitating the acquisition of musical cultural values is achieving learners' readiness to perceive music while the importance of cognitive teaching and learning aims becomes secondary.

The teacher's role becomes that of a helpmate whose task is to assist the children arrive at an understanding. Mastering a specific learning strategy is only the first step, which must be followed by appropriate application. It means that teachers should focus on creating favourable conditions for the development of appreciation and adequate self-assessment among learners, beware of smothering learners' innate initiative and creativity in problem solving and ensure freedom of choice in their learning about the world. Learners ought to be motivated to acquire musical cultural values through a personal understanding thereof, which is grounded in one's experience, desires and interests. Values acquisition is rooted in discussing musical cultural values of particular nations and countries - a process that should involve careful analyses of contexts such as time, space, social setting, history and geographical positioning and integrate fundamental descriptors (key concepts) both in regards to theory and learners' practical activity. It follows that the content of basic education should be taught with an approach that gives equal consequence to learners' physical, intellectual and spiritual needs. It means that teachers accept children as they are and respect their unique life experiences. Instead of focusing on lengthy recitals of biographical details, a brief reference to relevant additional sources should suffice to guide learners towards autonomous in-depth exploration of the issue. Overabundance of definitions and dry facts is often detrimental to learners' interest and rather conductive to indifference and a poor understanding of the topic. Consequently, in order to facilitate acquisition of musical cultural values, teachers should be competent not only in their own but also in other subjects, be proficient 
in foreign languages and technologically literate, know their learners' needs, interests and abilities as well as be able to suggest appropriate forms of social cooperation to specific situations in the teaching and learning process. All this is directed towards fostering a comprehensive understanding of relevant subject matter through a set of attitudes that find expression in the learners' values, principles and ideals and underpin their personal growth. Thus, the concept of musical cultural values should be construed not only as relevant to aesthetic culture but also as germane to the culture of coexistence, a culture of communication and interaction. Taking such a perspective should bear favourably on developing an understanding of cultural diversity and finding personal meaning in interaction with other people in a world of culture.

\section{Acknowledgement}

This work has been supported by the European Social Fund within the Project "Support for the implementation of doctoral studies at Daugavpils University", agreement No. 2009/0140/1DP/1.1.2.1.2/09/IPA/VAA/015.

\section{References:}

Bateson, G. (2000). Экология разума. Избранные статьи по антропологии, психиатрии и элистемологии [Ecology of the mind. Selected articles on anthropology, psychiatrics and epistemology]. Москва: Смысл.

Beļickis, I. (2000). Vèrtīborientētā mācību stunda [A values-oriented lesson]. Rìga: RaKa.

Beyers, R. N. (2009). A five dimensional model for educating the net generation. Educational Technology \& Society, 12(4), 218-227.

Bezborodova, L., \& Aliyev, U. (2002). Методика преподавания музыки в общеобразовательных учреждениях [Methodology of teaching music in general education institutions]. Москва: Академия.

Birzkops, J. (1999). Muzicēěsana kā labākā intelektuālo spēju attīstītāja [Music making as the best way to develop intellectual skills]. Riga: Liesma.

Bundsgaard, J. S., \& Hansen, T. I. (2011). Evaluation of learning materials: A holistic framework. Journal of Learning Design, 4(4), 31-44.

Capra, F. (2002). The hidden connections: Integrating the biological, cognitive and social dimension of life into a science of sustainability. New York: Doubleday.

Clark, E. T. (1997). Designing and implementing an integrated curriculum: A studentcentered approach. Brandon, VT: Holistic Education Press.

Creswell, J. (2003). Research design: Qualitative, quantitative, and mixed approaches. Thousand Oaks, CA: Sage.

Cropley, J. (1999). Definitions of creativity. Encyclopedia of creativity. San Diego, CA: Academic Press.

Forbes, S. H. (2003). Holistic education: An analysis of its ideas and nature. Brandon, VT: Foundation for Education Renewal.

Gang, P. (1993). Holistic education. In C. L. Flake (Ed.), Holistic education: Principles, perspectives, and practices (pp. 86-91). Brandon, VT: Holistic Education Press.

Gardner, H. (1993). Multiple intelligences: The theory in practice. New York: Basic Books. 
Ilisko, D. (2005). Pedagogical challenges for implementing holistic curriculum in Latvia. Journal of Teacher Education and Training, 5, 28-39.

Jorgensen, E. (1997). In search of music education. Urbana, IL: University of Illinois Press.

Katane, I. (2007). Paradigmas Latvijas izglìtības vidè mūsdienās. Monogrāfisko pētījumu sèrija "Izglìtības ekologiija" [Paradigms in contemporary educational environment of Latvia. Series of monographs "Ecology of education”]. Jelgava: LLU TF IMI.

Kopeloviča, A., \& Žukovs, L. (2004). Skolotāju izglìtība Latvijā, 1940-2000 [Teacher education in Latvia, 1940-2000]. Rìga: RaKa.

Kostakos, G. (2012). A tale of two UN processes: The Global Sustainability Panel and Rio+20. Global Education Magazine, 1, 49-53.

Krastiņa, E., \& Pipere, A. (2004). Mācību sasniegumu pašizvērtēšana [Self-evaluation of learning achievements]. Riga: RaKa.

Lemkow, A. F. (1990). The wholeness principle: Dynamics of unity within science, religion \&o society. Wheaton: Theosophical Publishing House.

Little, D. (1991). Learner autonomy 1: Definitions, issues and problems. Dublin: Authentik.

Maslo, I. (2006). Mācī̌sanās daudzveidības izpratne integratīvo procesu teorijā [Understanding diversity of learning in integrative process theory]. In I. Maslo (Ed.), No zināšanām uz kompetentu darbību. Mācǐšanās antropoloǵiskie, ètiskie un sociālkritiskie aspekti [From knowledge to competent action. Anthropological, ethical and sociocritical aspects of learning] (pp. 20-44). Rīga: LU Akādemiskais apgāds.

Miller, J. P. (1993). The holistic teacher. Toronto: OISE Press.

Miller, R. (2000). Caring for new life: Essays on holistic education. Brandon, VT: Foundation for Educational Research.

Nava, R. G. (2001). Holistic education: Pedagogy of universal love. Brandon: Foundation for Educational Renewal.

Quince, P. (2006). Education for sustainability. Education for Meaning and Social Justice, 19(14), 30-34.

Palmer, P. J. (1998). The courage to teach: Exploring the inner landscape of teacher's life. San Francisco: Jossey-Bass Publishers.

Pelnēna, M., \& Kḷaviņš, M. (2009). Izglītība ilgtspējīgai attīstībai: pieredze un iespējas Latvijā. [Education for sustainable development: Experience and opportunities in Latvia]. Vides izglìtība augstskolā [Environmental education at the tertiary level] (pp. 69-88). Rīga: LU Akadēmiskais apgāds.

Powell, K. C., \& Kalina, C. J. (2009). Cognitive and social constructivism: Developing tools for an effective classroom. Education, 130(2), 241-250.

Rose, J. (2005). Educating the whole person: An orthodox perspective. In P. Schreiner, E. Banev \& S. Oxley (Eds.), Holistic education resource book: Learning and teaching in an ecumenical context (pp. 69-123). New York, München, Berlin: Waxmann Münster Verlag GmbH.

Rogers, C. R. (1967). Person to person: The problem of being human: A new trend in psychology. Lafayette, CA: Real People Press.

Rubene, Z. (2008). Kritiskā domāšana studiju procesā [Critical thinking in the study process]. Rīga: LU Akadēmiskais apgāds. 
Ruismäki, H., \& Ruokonen, I. (2009). Children's right to good music education: Some practical applications and synthesis towards the ideals of the children's rights declaration. In J. Davidova (Ed.), Problems in music pedagogy (Volume 4; pp. 717). Daugavpils: Daugavpils University Academic Press "Saule”.

Salìte, I. (2002). Ilgtspējīgas izglìtības mērḳis skolotāju skatījumā [The aim of sustainable education through the eyes of teachers]. Skolotājs [The Teacher], 5, 5-7.

Salite, I. (2008). Educational action research for sustainability: Constructing a vision for the future in teacher education. Journal of Teacher Education for Sustainability, 10, 5-16.

Salite, I., \& Pipere, A. (2006). Aspects of sustainable development from the perspective of techers. Journal of Teacher Education and Training, 6, 15-32.

Schreiner, P. (2005). Contributions to holistic education from different theories. In P. Schreiner, E. Banev \& S. Oxley (Eds.), Holistic education resource book: Learning and teaching in an ecumenical context (pp. 35-55). New York, München, Berlin: Waxmann Münster Verlag GmbH.

Sîle, M. (2000). Veseluma pieeja bèrna attīstībā klavierspēles mācību procesā [An entirety approach to the child's development in piano playing]. Unpublished doctoral dissertation, University of Latvia, Riga, Latvia.

Sterling, S. (2004). Sustainable education. Re-visioning learning and change. Green Books: The Schumacher Society.

United Nations Economic Commission for Europe. (2011). Learning for the future: Competences in education for sustainable development. Geneva: United Nations Economic Commission for Europe.

Wilber, K. (2001). A theory of everything: An integral vision for business, politics, science, and spirituality. Boston: Shambhala.

Zariňš, D. (2003). Mūzikas pedagogijas pamati [Fundamentals of music pedagogy]. Riga: RaKa.

\section{Correspondence:}

Jel̦ena Badjnova, Ph.D. candidate, Department of Pedagogy and Psychology, Faculty of Education and Management, Daugavpils University, 1 Parādes Street 1, LV-5401. Email: helenija@inbox.lv 